\title{
RECONSTRUCTION OF PAST ANTHROPOGENIC IMPACT INTENSITY IN LAKE ENGURE USING SEDIMENTARY RECORD ANALYSIS
}

\author{
Māris Kḷaviṇš*, Agnese Pujāte*, Ilga Kokorīte*, Laimdota Kalniṇa*, Valērijs Rodinovs*, \\ Linda Ansone*, Jonas Mažeika**, Maruta Jankēvica*, Egils Bogans ${ }^{\star * *}$, Anda Švāgere ${ }^{\star * *}$ \\ * Faculty of Geography and Earth Sciences, University of Latvia, Raina bulv. 19, Rīga LV-1586, LATVIA; \\ e-mail: maris.klavins@lu.Iv \\ ** Radioisotope Research Laboratory, Nature Research Centre, T. Ševčenkos 13, Vilnius 03223, LITHUANIA \\ ${ }^{* * *}$ Institute of Atomic Physics and Spectroscopy, University of Latvia, Raina bulv. 19, Rīga LV-1586, LATVIA
}

Contributed by Māris Kḷavinšs

\begin{abstract}
Environmental pollution with trace elements is considered as one of the most important environmental problems. Analysis of trace element accumulation in sedimentary phases of lakes may reflect the overall regional pollution level, and analysis of trace element accumulation patterns in sediment profiles can help to reconstruct the history of anthropogenic impact. The aim of this study was to analyse trace element concentrations in sediments of Lake Engure in Latvia and to determine factors influencing their availability. The metal concentrations in sediments of Lake Engure are at background levels, especially compared with metal concentrations in West European countries. However, the change in element concentration in sedimentary profiles provides information about trends of recent accumulation (within the last 100 years) and on the balance between natural and human-induced accumulation processes.
\end{abstract}

Key words: lake sediments, paleolimnology, trace and major elements, organic matter, pollen, spectrophotometry.

\section{INTRODUCTION}

Investigation of lake sediment composition can provide valuable information about lake development character and thus can be used to study long-term, natural, human and climate impacts on lakes and their basins (Dearing et al., 2008). Coastal lakes, particularly former Littorina Sea lagoons, are shallow water basins in which sedimentary records can indicate past natural communities, climate and human activities (Saunders et al., 2008). The study of lake sediments can be used to determine paths of environmental change during lake development (Cohen, 2003). Likewise, lake sediments can been used to study periods of forest fires, climate-induced changes in vegetation, and humaninduced changes to organic matter inputs and primary producer community structure (Waters et al., 2009).

Lake Engure is the largest water basin in the western coastal area of the Gulf of Riga, and has been developed due to processes at several stages of the Baltic Sea evolution. The first basin influencing the area of Lake Engure was the Baltic Ice Lake. The area of the sloping Baltic Ice Lake Plain (25-30 to $8-10 \mathrm{~m}$ above sea level), presently located between the Baltic Ice Lake and Littorina Sea coastline, is covered throughout by sand and gravel deposits (Eberhards and
Saltupe, 2000) that surround the lake's western and southern coast (Fig. 1). Sandy inland dunes were formed in this area after the regression of the Baltic Ice Lake, due to poorly developed vegetation and strong winds. The Sea level fell during the Yoldia Sea stage, when brackish waters entered into the Baltic Sea depression. Water level of Yoldia Sea was about 5-6 m lower than presently in the area of Lake Engure (Гринбергс, 1957).

Sediments of the basin are not found in the coastal area of lake, and there are no clear traces of them in the lake itself. However, the subdivision of bottom sediments from the Yoldia Sea is difficult due to very poor or mixed faunal and floral assemblages (Raukas, 2000). In Lake Engure and its surrounding areas, there are also weak traces of sediments accumulated during the Ancylus Lake, the fresh water basin that replaced the Yoldia Sea after the isostatic rise of south Scandinavian landforms. This can probably be explained by erosion of sediments during the Littorina Sea transgression, when rising oceanic levels broke through the Great Belt. The water level of this brackish basin increased 5-6 m above the present in the lake area. The area of present Lake Engure and low lying surrounding areas were a lagoon of the Littorina Sea. Later the deepest part of the Littorina Plain was separated from the sea, resulting in the Littorina 


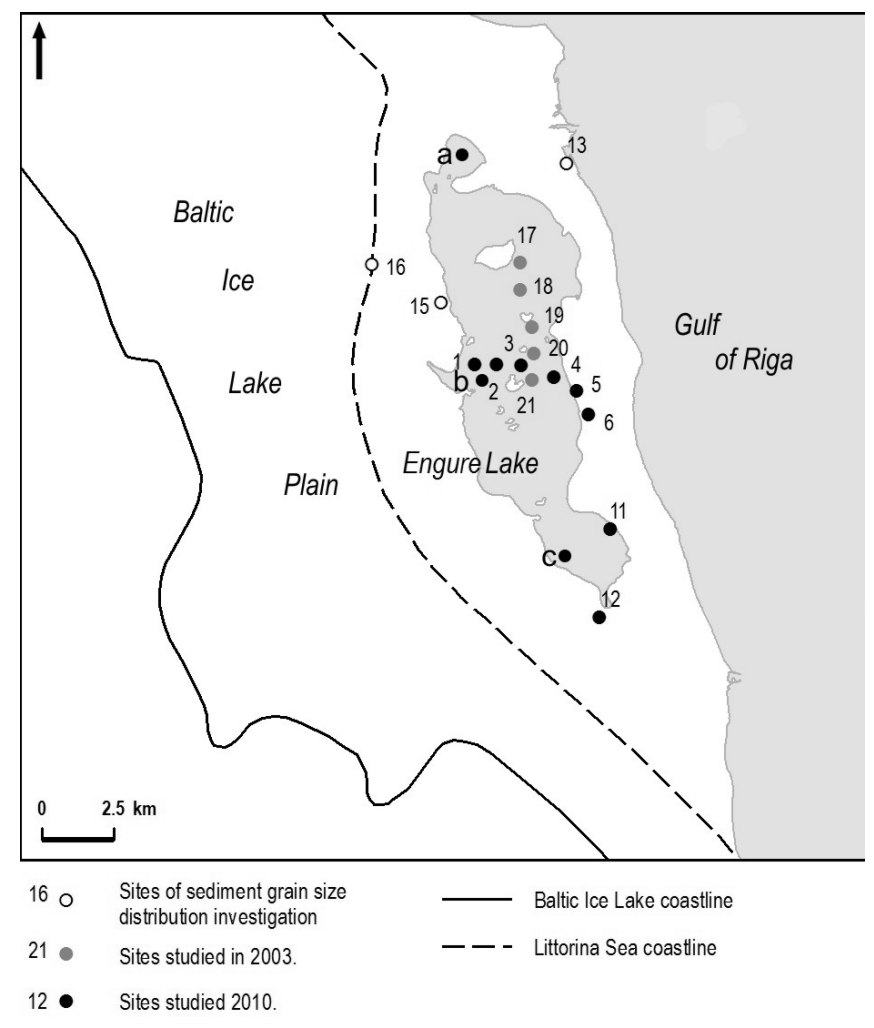

Fig. 1. Location of the study area and lake sediment sampling sites.

Sea regression. During that time, the water level fell, forming a lake. A long spit about $20 \mathrm{~km}$ in length, consisting of sands and gravel, appeared between Lake Engure and the Gulf of Riga after the Littorina Sea regression. Initially it occurred as a large underwater bar, which later appeared above water and was covered by parallel dune ridges, separating the lagoon from the open sea (Eberhards and Saltupe, 2000). The basin conditions then changed from brackish to freshwater. Nowadays, a $1.5-\mathrm{km}$ to $2.5-3-\mathrm{km}$ wide belt of land separates Lake Engure from the Gulf of Riga (Fig. 1). The lake depression is shallow, with uneven bottom relief, which is covered by sand, silty clay, silt with organic matter and gyttja. The Mērsrags Canal was excavated in 1842, which caused an abrupt decrease in lake water level by 1.5 to $2 \mathrm{~m}$. This created a new land area suitable for agriculture, in the zone previously covered by lake waters. However, large areas of the flat lake bank slopes became favourable for fen peat formation, but some sandy areas distant from lake became dry and new dune formation processes took place.

Lake sediments in Latvia have been investigated by geological, paleoecological and paleobotanical methods during the last decades (Alksnītis, 1995; Juškevics et al., 1999; Eberhards and Saltupe, 2000; Malnace, 2003; Rumpe, 2003). Although this type of information provides only basic information about lake genesis and development, the obtained results are very important for decision making and lake management. Lake Engure is presently surrounded by forest (Vìksne, 1997). The sources of pollution from human impact are probably aerial or along the inflowing rivers, like Dzedrupe, Dursupe, Jurǵupe, Kalnupe, and Melnupe. Pa- leolimnological, paleobotanical and chemical investigations of lake sediments using instrumental analytical methods can help to reveal processes and impacts influencing lake development and human pressures, especially during the last centuries. Analysis of major and trace elements in lake sediments has been used as an efficient tool to study spatiotemporal patterns of sedimentary records (Renberg et al., 2001; Lepane et al., 2010), diatom assemblages, phosphorus and organic carbon (Anderson et al., 1993; Marchetto and Musazzi 2001; Rasanen et al., 2007).

The aim of this study is to analyse sedimentary records of Lake Engure formed during the last few hundred years, in relation to human impact.

\section{MATERIALS AND METHODS}

This study includes a review of results from previous investigations, field work and laboratory analyses. Geological sediment sounding and geological coring were carried out in nine sites to determine lake sediment structure, and to identify the most representative site for sediment sampling. Sediment dating using ${ }^{14} \mathrm{C}$ method was conducted at the Tallinn University of Technology. Sediment dating of the upper $30 \mathrm{~cm}$ layers has made using ${ }^{210} \mathrm{~Pb}$ analysis by known methods (Schönhofer and Wallner, 2001).

Geological coring was carried out using an Eijelkamp soft sediment geological corer with closed chamber. Core size was $5 \mathrm{~cm}$ in diameter and $50 \mathrm{~cm}$ in length with a sample volume of $10 \mathrm{ml} / \mathrm{cm}$. Sequential loss on ignition (LOI), a common and widely used method to estimate organic matter $(\mathrm{OM})$ and carbonate matter (CM) content of sediments (e.g., Dean, 1974; Bengtsson and Enell, 1986; Heiri et al. 2001) was determined for Lake Engure sediments in three sites:

1) lake sediments at the southern part of lake (core No. 11), $\left(57^{\circ} 12 ` 520 ; 23^{\circ} 08 \times 868\right)$;

2) a fen at the southern shore of the lake (core No. 12). The fen area was covered by reed Phragmites australis and a smaller area was occupied by lesser bulrush Typha angustifolia, common bulrush Typha latifolia, common club-rush Scirpus lacustris, water Horsetail Equisetum fluviatile, and Bog-myrtle Myrica gale ( $57^{\circ} 17^{`} 271$; $\left.23^{\mathrm{O}} 15^{`} 912\right)$;

$3)$ central part of the lake $\left(57^{\circ} 26^{`} 256 ; 23^{\circ} 10^{`} 584\right)$.

Sediment subsamples were decomposed and atomised in a pyrolytic furnace RP-91C. Mercury concentrations in the samples were determined using an Atomic Absorption Spectroscopy (AAS) analyser Lumex RA-915+. The operation of the RA 915+ analyser is based on differential Zeeman atomic absorption spectrometry with high frequency modulation of light polarisation. For analysis of solid samples this allows high sensitivity at at a concentration of $0.5 \mu \mathrm{g} / \mathrm{kg}$, while eliminating the influence of molecular absorption, light scattering and other disturbing factors. $\mathrm{Hg}$ concentration in a sample is obtained by applying a cal- 
ibration coefficient, determined based on a reference standard. There is no additional sample preparation needed, and the analysis time is 1-2 minutes per sample.

Dried and sieved $(<100 \mu \mathrm{m})$ subsamples $(\sim 1 \mathrm{~g})$ were digested with $50 \% \mathrm{HNO}_{3}$ and $30 \% \mathrm{H}_{2} \mathrm{O}_{2}$ on a hot plate at 70 $\pm 5{ }^{\mathrm{O}} \mathrm{C}$ (Csuros and Csuros, 2002). Metal concentrations were measured by flame atomic absorption (Perkin Elmer 503). The reliability and accuracy of analytical results were checked using blank and reference samples (SLRSS-2 river water, BCSS- coastal marine sediments; Analytical Chemistry Standards NRC, Canada). The results from the analysis of SRM were all within the $95 \%$ confidence level of the SRMs.

Sediments for pollen analysis were subsampled from cores No. 12 and No. 18. The sediment samples $(50 \mathrm{~cm}$ long monoliths) were placed in a special cartridge and wrapped in polyethylene film to preserve natural moisture, brought to the laboratory and subsampled into $5 \mathrm{~cm}$ sections. Pollen extraction and analysis was based on a standard method described by B. E. Berglund and M. Ralska-Jasiewiczowa (1985). A Carl-Zeiss light microscope Axiostar with magnification 400-1000 times was used for pollen counting.

At least five hundred palynomorphs, excluding spores and aquatic plant pollen were counted for each sample. Particular attention was given to the indentification of Cerealia type pollen, weeds and other anthropogenic indicators, like Urtica, Plantago, Rumex and others, as well as charcoal dust particles (20-100 $\mu$ ) presence (Behre, 1981; Brostorm, 2002). Palaeoalgological analyses were performed on pollen slides that were chemically treated for the separation of pollen and spores (Jankovska and Komarek, 2000).

\section{RESULTS}

Lake Engure belongs to the transitional-accumulative type of lake (Placēna, 1995). Thickness of sediment layer with organic matter, which is mainly composed of silty or clayey gyttja, varies from 1-2 $\mathrm{m}$ in the northern part of lake to $3 \mathrm{~m}$ in the northern part of the lake, due to uneven relief of the lake depression bottom, as well as the complicated hydrological regime of the lake that involves water level changes caused by both natural and anthropogenic conditions.

Six local pollen zones were identified in obtained pollen diagram (core No. 18) (Fig. 2). Pollen spectra and their composition from analysed sediments reflects vegetation development in the surrounding of the lake since the second part of the climatic optimum, from the time when broadleaved forests were common around the lake, through mixed coniferous forest to the present compostion with a component of dedicious tress today.

Pollen indicative of anthropogenic activities, including cultivated plants (Cerealia) and weeds is in greater relative densities in the very upper part $(30-40 \mathrm{~cm})$ and at a depth of 210-250 cm (Fig. 2). Proof of the human presence and activities are indicated by weeds such as nettle (Urtica), goosefoot (Chenopodium), sorrel (Rumex), horsetail (Equisetum), mugwort (Artemisia), knotgrass (Polygonum) and ruderal plant pollen presence in the sediment layers, conditionally classified to two time periods: the Late Atlantic-Subboreal and the last century. Increasing volume of Cerealia, Cannabis and Avena pollen, as well as charcoal dust is evident in these periods in the pollen diagram (Fig. 2).

Large algae diversity in the sediments indicate eutrophication processes in the basin. Their volume changes in the sediment section, reflecting water level changes in the lake. The largest number and diversity of algae is found at the time which according pollen data can be conditionally dated to the end of the climatic optimum. This period is characterised by decrease of broadleaved pollen volume and increase of spruce pollen, reflecting changes in vegetation composition around the lake. A significant increase in algae amount

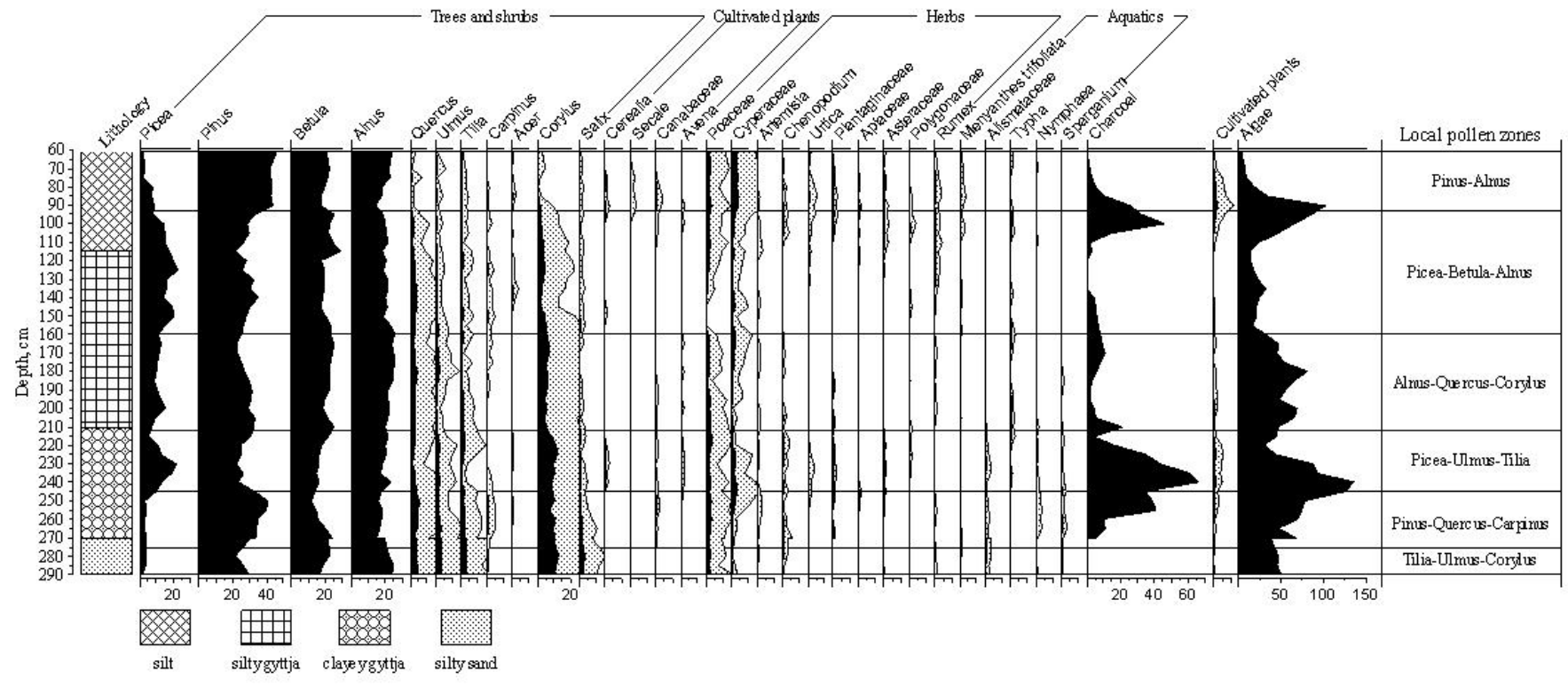

Fig. 2. Pollen percentage diagram from Engure Lake sediments of core No. 18, sampled in the northern part of lake (Fig. 1). 
is observed also in the upper interval of the sediment section, in which green algae Pediastrum, including Pediastrum boryanum, P. b. var longicorne, P.b. var undulatum, $P$. integrum, $P$. int. var perforatum. $P$. kawraiskyi, $P$. duplex and $P$. muticum are found in large densities. The largest amounts of algae likely occurred when the water level was lowered in the lake.

Cyanobacteria Anabena spp. are found in whole section, but in large amounts in the upper part of the section, probably due to lower water levels and anthropogenic influence. The most common fauna remains are from Cladocera and Insecta, less of Protozoa and Alona.

Pediastrum, represented by P. boryanum, P. kawraiskyi and P. duplex dominate in Lake Engure. Pediastrum boryanum presently is the most abundant of all Pediastrum species in Latvia. It is relatively insensitive to trophic conditions in the lake, and is more common in eutrophic waters. $P$. kawraiskyi is common in the Baltic sea region, and Pediastrum duplex prefers relatively warm and eutrophic conditions.

Results of LOI analysis show that a larger amount of organic matter and carbonates are found in sediments that are up to a depth of $86 \mathrm{~cm}$, where the minerogenic matter component is lower (Fig. 3). These results indicate the onset of lake eutrophication and overgrowing processes, which are dated at a time before approximately 5500 calendar years. The lithological composition of sections show sand sediment change from sand at the bottom to mixing with organic matter from bottom upwards. At depths less than 86 $\mathrm{cm}$, the component of sand part decreases as the amounts of silty gyttja increase. Such mixed sediment composition indicate an unstable hydrological regime.

Decrease of carbonate and increase of the minerogenic particle amounts were found at depth $78 \mathrm{~cm}$, suggesting a water level increase in the basin at time of formation of this sediment layer. Fluctuations of the curves are significant, which indicates unstable conditions in the sedimentation environment. There is a good correlation between moisture and organic matter content.

The sediment composition changes during the last 100 years reflect a rapidly changing environment in the lake basin and waterbody. These changes are particularly seen in the basic components of the lake sediments, such as organic matter $(\mathrm{OM})$ and carbonate content (CM) (Fig. 4).

Analysis of organic matter (OM) and carbonates (CM), estimated as loss on ignition (LOI) in samples from the upper layers of the sedimentary phases (Fig. 4), indicates significant differences in the accumulation processes in the lake water body, and also intensification of accumulation processes during the last decades. A specific feature of Lake Engure is very high heterogeneity of sedimentation conditions. During the last 50 years, in the central part of the lake (Station b), OM content was randomly increasing, indicating intensive, but stable production of organic substances and their sedimentation, but the organic matter sedimentation was less intensive than before 1960. In sediments from the northern part of the lake (Station a) organic matter content increased in sediments up to 1990, followed by a decrease after this time. In the southern part of the lake organic matter sedimentation conditions during the last decades has been relatively stable. Carbonate sedimentation conditions have been stable in the central part of the lake, but have significantly increased during the last 50 years both in southern and northern parts.

An essential element influencing development of biota in waterbodies is phosphorous (Fig. 5). Of especial importance is biologically available phosphorus, which promotes eutrophication and growth of macrophytes in lake. Phosphorous concentrations in southern and northern parts of the lake slightly increased starting from the middle of the $20^{\text {th }}$ cen-

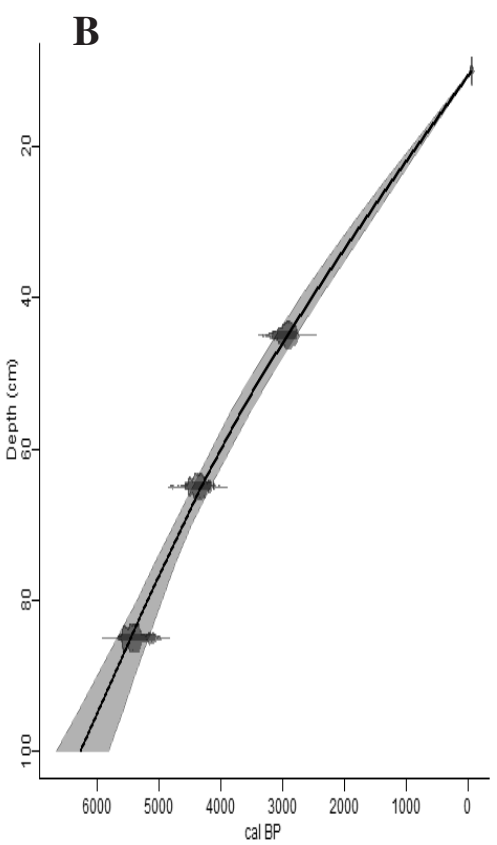

Fig. 3. Results from core No. 12 deposit investigation sampled in the fen at the southern end of Lake Engure: percentage diagram of LOI results (A); depth-age model (B) 
OM content, $\%$

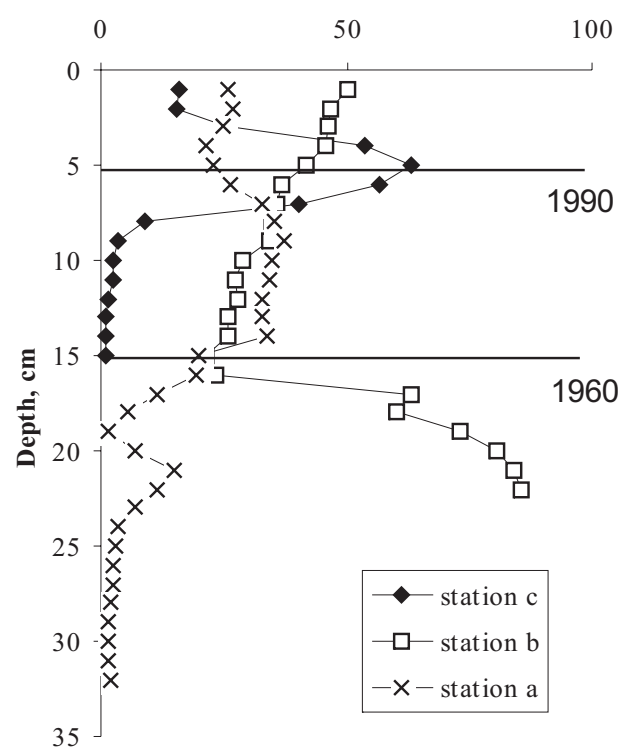

CM content, \%

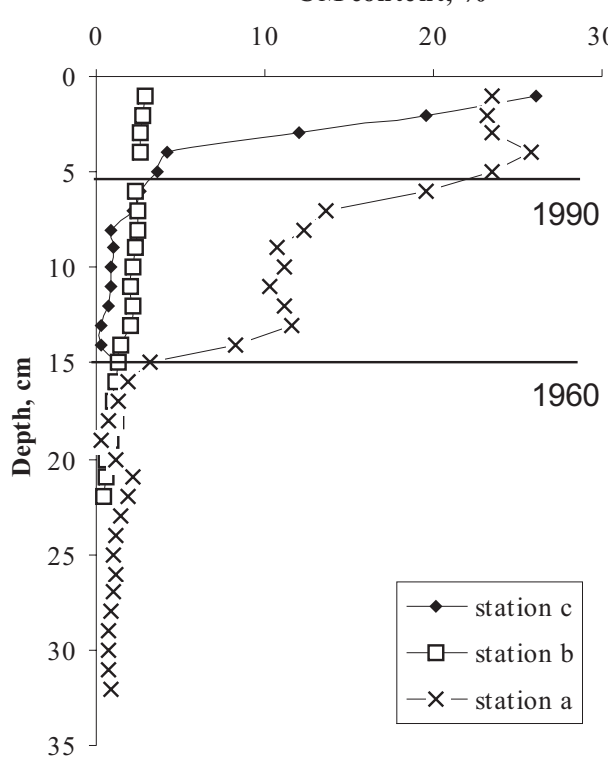

Fig. 4. Concentration of organic matter $(\mathrm{OM})$ and carbonates $(\mathrm{CM})$ (estimated as loss on ignition (LOI) in the upper layers of Lake Engure sediment profiles (sampling sites in the lake body (a, northern part; $\mathrm{c}$, southern part - b centre of the lake). tury, but after 1990 phosphorus concentrations decreased. However, in the central part of the lake, which represents the major part of the waterbody the concentrations during the last 30-40 years have significantly increased, indicating major accumulation of phosphorus.

Major and trace element accumulation in lake sediments was determined in a dated sediment profile covering the last century (Figs. 6, 7). In very recent sediments Na concentrations are relatively lower than $\mathrm{K}$ concentrations, but in older sediments $\mathrm{K}$ concentrations are higher. Concentrations of $\mathrm{Mg}$ in sedimentary records seem to have changed little during the last centuries (Fig. 6), in contrast to $\mathrm{Ca}$, which has similar chemical and geological behaviour. For both elements high concentrations in deeper layers of sediment profile are relatively common, but $\mathrm{Ca}$ concentrations have a

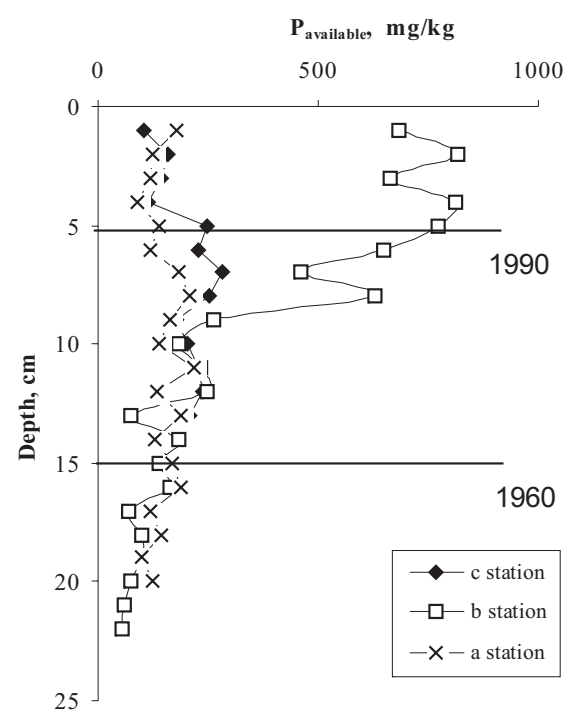

Fig. 5. Concentration of biologically available phosphorous in the upper layers of Lake Engures sediment profiles (sampling sites in the lake body (a, northern part; c, southern part - b centre of the lake) significant variability also in recent sedimentary profiles, indicating high natural variability of sedimentation conditions and weathering of $\mathrm{Ca}$ containing minerals in the lake basin. Fe concentrations in Lake Engure sediment profiles (Fig. 6) have decreased, possibly due to changes in oxygen conditions. Only Fe (III) tends to form stable sedimentary phases, but if anoxic events become frequent Fe (III) can be reduced to soluble forms of $\mathrm{Fe}$ (II) and the iron accumulation is decreased. In recent decades, $\mathrm{Fe}$ accumulation has been increasing.

Influences of geochemical processes are evident in metal concentrations, particularly for $\mathrm{Zn}$ and $\mathrm{Pb}$ (Fig. 7). During
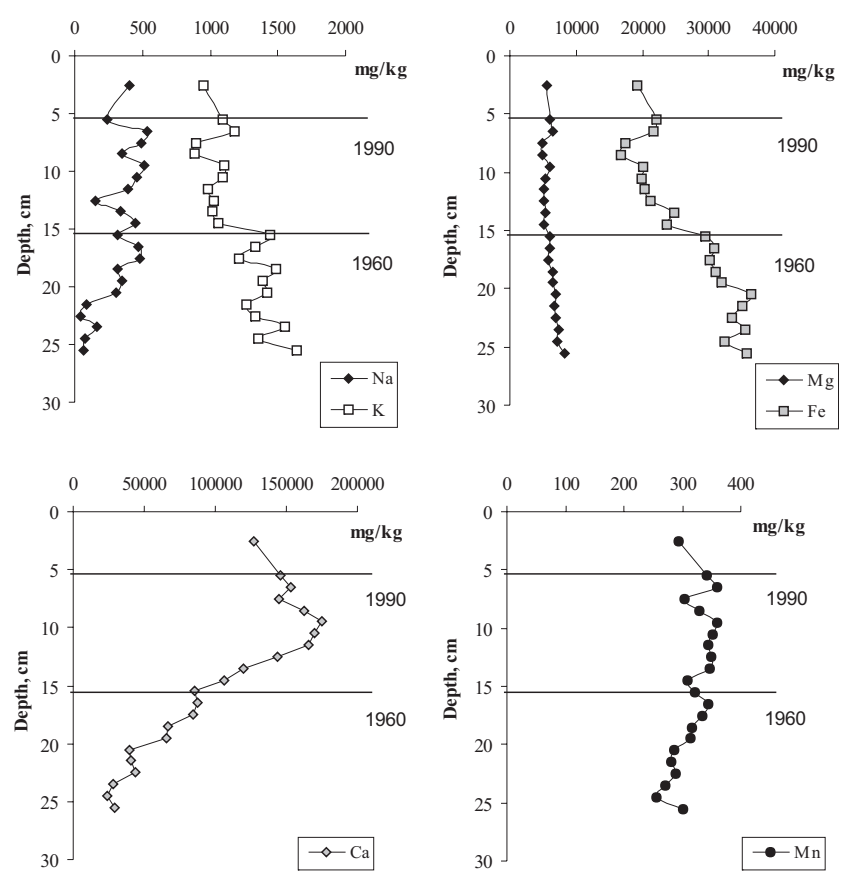

Fig. 6. Concentration of major metals in the upper layers of Lake Engures sediment profiles (sampling sites in the lake body - b centre of the lake) 

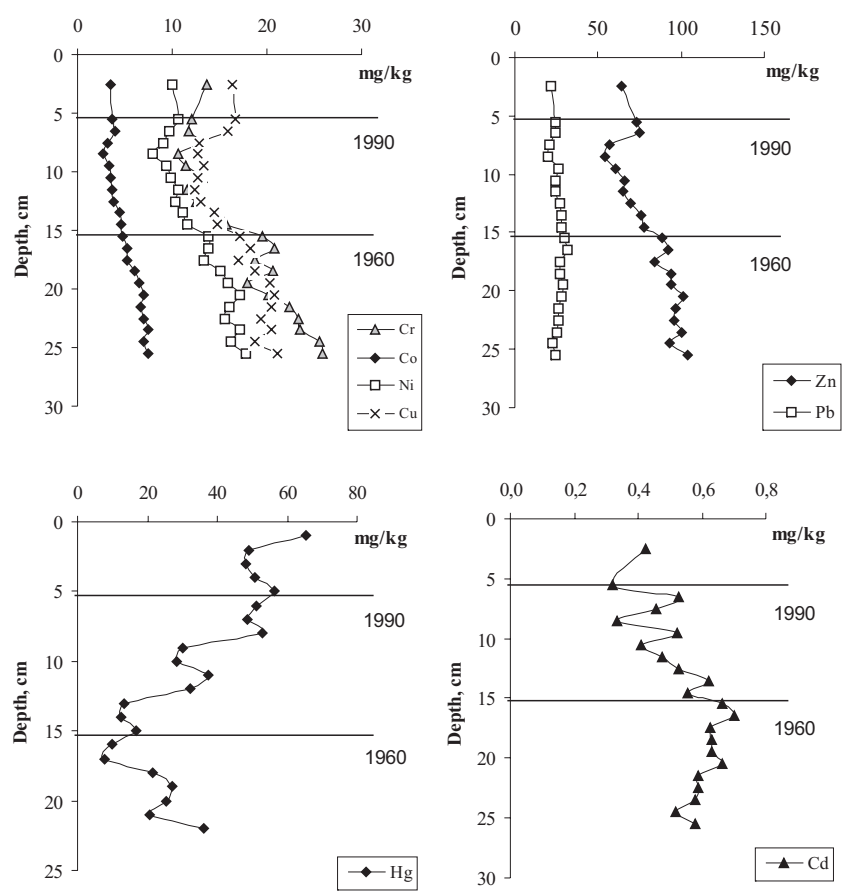

Fig. 7. Concentration of trace elements in the upper layers of Lake Engures sediment profiles (sampling sites in the lake body - b centre of the lake).
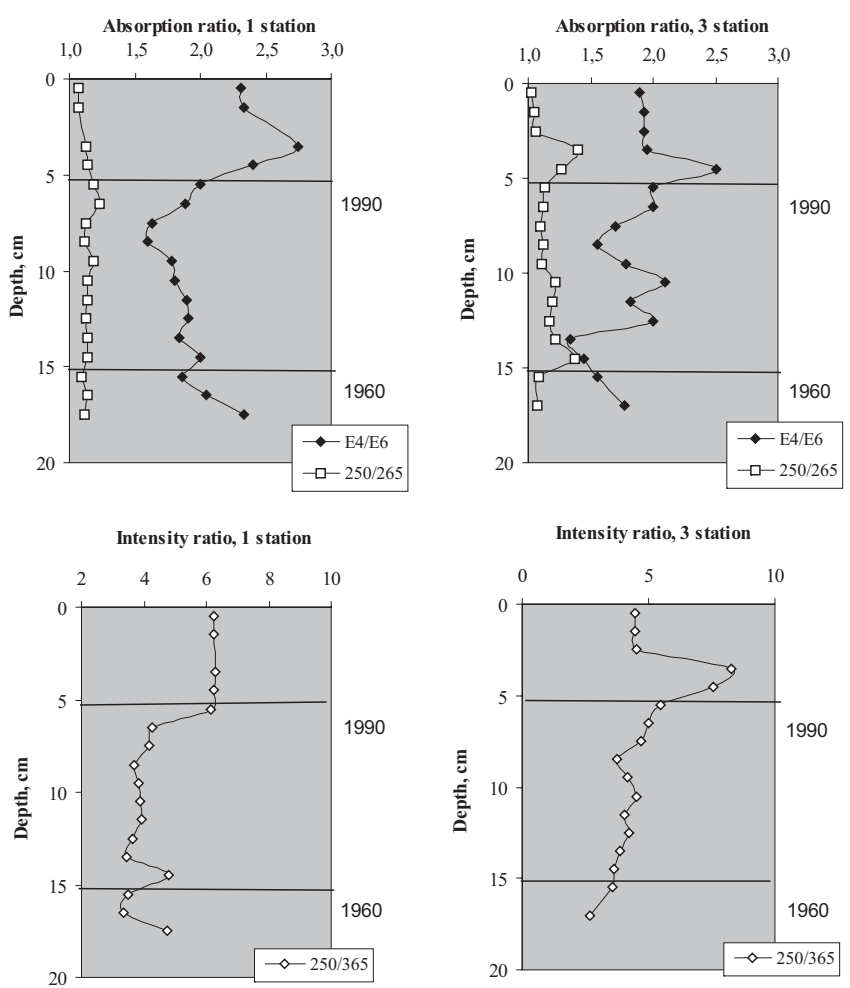

Fig. 8. Spectral absorption ratios (sorption at $250 \mathrm{~nm}$ in respect to sorption at $365 \mathrm{~nm}-250 / 365$ and sorption at $410 \mathrm{~nm}$ in respect to sorption at 640 $\mathrm{nm}-\mathrm{E}_{4} / \mathrm{E}_{6}$ ) in the upper layers of Lake Engures sediment profiles (sampling sites in the lake body - station 1 and 3).

last 50 years, there has been a large decrease of concentrations of the trace elements associated with human impact. On one hand, this indicates low anthropogenic pressure, but this decrease may be due to natural geochemical processes

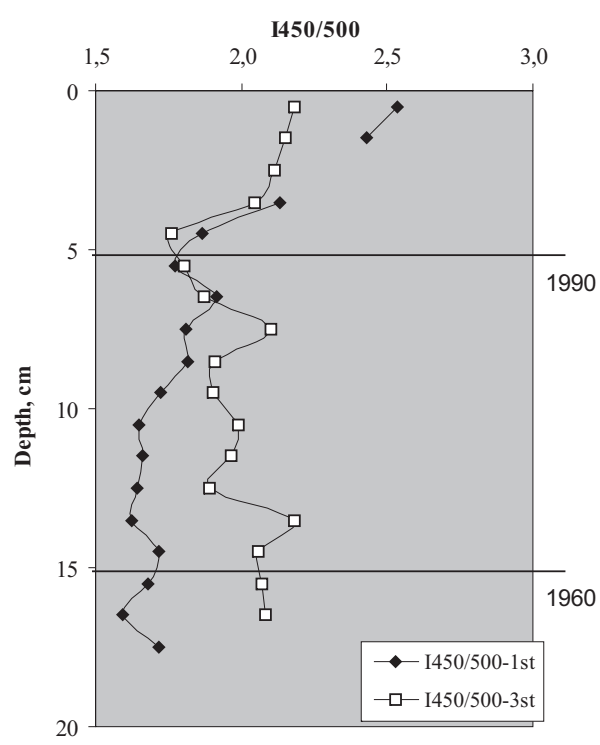

Fig. 9. Fluorescence emission intensity ratios (intensity at $450 \mathrm{~nm}$ in respect to intensity at $500 \mathrm{~nm}-\mathrm{I} 450 / 500$ at excitation wavelength $375 \mathrm{~nm}$ ) in the upper layers of Lake Engures sediment profiles (sampling sites in the lake body - stations 1 and 3).

possibly altered by building of the Mērsrags Canal in 1842 . The only one element with an increasing tendency of values in sediments during the last 50 years was mercury, which does indicate recent human impact.

Changes in Lake Engure sediment composition occurred at a time when traditional low-intensity agricultural activities in the lake basin were common (the lake basin is relatively sparsely settled and forests and natural meadows dominate). Thus, the sedimentary records of elemental composition can indicate human-induced and natural loading coming from lake basin. In this respect, the study of organic matter composition is important. Ratios of UV adsorption ratios and fluorescence intensity ratios were determined (Figs. 8, 9) as suggested previously for study of changes of organic matter composition in lake sedimentary records (Lepane et al., 2010). The UV absorption ratios show differences in sedimentary organic matter properties and heterogeneity with the lake water body itself. Organic matter of Lake Engure sediments showed high variability of traditionally widely used $\mathrm{E}_{4} / \mathrm{E}_{6}$ ratio (Fig. 8). UV sorption ratio in the near UV region, which estimates the amount of aromatic compounds (UV sorption at $250 \mathrm{~nm}$ against UV sorption at $265 \mathrm{~nm}$ ) does not much changes in the sediment chronosequence. Also fluorescence intensity ratios demonstrate, reasonable degree of variability, thus possibly reflecting changes of sediment composition (Fig. 9).

\section{DISCUSSION}

Sediment accumulation conditions changed during lake development, shown by changes in sediment composition, including chemical parameters. Marine waters inflow into the lake through the Mērsrags Canal during autumn and spring periods. Strong winds promote active water layer mixing 
and probably, influence also the very upper soft sediments, as Lake Engure is very shallow. LOI results alaso indicate mixed sediment composition. The lake eutrophication and overgrowing processes started approximately 5500 calendar years ago. The lithological composition of sediment profiles shows a change from sand sediments to sand with organic matter indicating unstable and changing conditions. According to LOI data, an increase in carbonates in lake sediments occurred in the last 150 years, after building of the Mērsrags Canal in 1842. These changes are not observed in the southern part of lake, particularly in the fen part, which can be explained both by the large size of the lake basin and completely different deposit accumulation conditions in the southern part, which were not strongly connected to the processes in lake itself.

The algae records indicate the largest abundance of algae in the very upper part of lake sediments. The abundance of green algae decreased in shallow sediments, but Cyanophyta (Anabena) algae abundance significantly increased. These changes likely resulted due to lowering of the water level lowering in the lake and strong human influence.

Pollen data indicate comparatively weak traces of human presence and activity, but there are two intervals in lake sediment section, where density of weeds and ruderal plant pollen, like nettle, goosefoot, sorrel, horsetail, mugwort and knotgrass, were increased. These intervals conditionally can be attributed to the Late Stone Age and the last two centuries. Such pollen records are characteristic for sediment records from the northern part of lake, and can be explained by sandy soils around the lake. The cereals pollen found in the lake sediments were probably dispersed from the surrounding areas by wind or inflowing river streams, which indicates possible crop growing in the lake catchment area. Pollen data from different parts of Lake Engure sediments provides evidence of paleovegetation during lake sediment accumulation, which probably can be explained by erosion or redeposition of sediments caused by different sedimentation conditions and the complicated hydrological regime in the large basin.

Trace and major element changes in Lake Engure sedimentary profiles have been affected in the last centuries by processes happening during lake development, natural variability of the bedrock in the lake basin, character of land use and human impacts. Sediment composition analysis of major constituents (carbonates and organic matter) and nutrients indicated significant heterogeneity in different subbasins of lake and reduced water flow mobility within the lake water body, due to overgrowth with macrophytes.

Different element groups and their changes in sedimentary profiles demonstrate different behaviour, largely due to their sources and processes influencing element accumulation. Na and $\mathrm{K}$ concentrations are affected by water inflow from the lake basin, while $\mathrm{Na}$ concentrations are raised by inflow of brackish waters through the Mērsrags Canal. K, as a nutrient, is consumed during the vegetation season by macrophytes. As a result, $\mathrm{K}$ and $\mathrm{Na}$ concentrations change in opposite directions, $\mathrm{Na}$ concentrations increased $\mathrm{K}$ concentrations decreased (Fig. 5).

Relatively low concentrations of $\mathrm{Na}$ in very recent sediments and higher $\mathrm{K}$ concentrations may indicate decay of higher vegetation litter and release of biogenic $\mathrm{K}$, and a low impacts of brackish waters from Gulf of Riga on the sedimentary composition. A major increase of $\mathrm{Na}$ concentrations occurred in sediments from a depth of 30-50 cm, which roughly corresponds to the period after building of the Mērsrags Canal in 1842, when the lake level significantly decreased, inflow of brackish waters from the Gulf of Riga became possible. In deeper sediment layers K concentration was also higher, and $\mathrm{Na}$ concentration was lower. Historically, K concentrations were elevated probably due to the biogenic origin of $\mathrm{K}$ in the aquatic environment.

$\mathrm{Ca}$ and $\mathrm{Mg}$ concentrations in sedimentary records differ from those of all other studied elements and seemingly are not much affected by anthropogenic pressure (Fig. 5), as elevated concentrations are common in deepest sedimentary layers when intensity of carbonate mineral weathering was likely a major factor affecting the pattern of changes of both elements. Significant variability of Ca concentrations in recent sedimentary profiles probably indicates high natural variability of sedimentation conditions and weathering of Ca-containing minerals in the lake basin.

Concentrations of trace elements like $\mathrm{Pb}, \mathrm{Co}, \mathrm{Ni}, \mathrm{Cu}$ and elements associated with human activities (as $\mathrm{Zn}$ ) may can be used to identify and investigate changes in loading of human-caused pollution (Fig. 6). The present study indicates a low recent increase of these contaminants in sediments of Lake Engure.

Results obtained in this study reveal different sedimentation conditions in the lake regarding geological structure, composition and palaeoenvironmental indicators. This study indicates that investigation of such large shallow basin as Lake Engure is complicated and provides diverse results due to different sedimentation conditions and local factors.

In conclusion, sediments in the lake depression and surrounding area have been accumulated under conditions of changing basins of the Baltic Sea stages, geological processes, climate and human impact. Different sediment characteristics can be explained by differing sedimentation conditions in the large basin. Excavation of the Merrsrags Canal caused changes in sedimentation in the entire lake and has been recorded in the sediment composition.

Pollution has been reflected by concentrations of major and trace elements in sediment cores.

Pollen data show weak traces of human activity in lake sediments: two intervals (Late Stone Age and last 200 years) can be identified from sediment sequences. Algae records indicate a significant increase of Cyanophyta algae in sediments accumulated during the last 200 years, caused by human activities influence. 
The metal concentrations in sediments of lakes in Latvia are at background levels. This can be explained by geochemical factors and abundance of sedimentary deposits in the drainage basins, as well as minimal anthropogenic load. However, direct anthropogenic impact was evident regarding point sources and transboundary transport. Analysis of elemental composition of sediment profiles provided information about the changes of human-induced and natural loading within the lake basin.

\section{REFERENCES}

Alksnītis, R. (1995). Pārskats par ezeru sapropeḷu atradņu meklēšanas darbiem Talsu, Tukuma, Kuldīgas, Saldus un Dobeles rajonos [Review of the efforts of searching sapropel deposits in the districts of Talsi, Tukums, Kuldīga, Saldus and Dobele]. Valsts Ģeolog̣ijas dienesta fonds, inv. nr. 11507.

Anderson, N.J., Rippey, B., Gibson, C.E. (1993). A comparison of sedimentary and diatom-inferred phosphorus profiles: Implications for defining pre-disturbance nutrient conditions. Hydrobiologia, 253, 357-366.

Anonīms (2012). Latvijas Dabas Fonds. EEDP dabas aizsardzības plāns http://www.ldf.lv/pub/?doc_id=28009.

Behre, K.E. (1981). The interpretation of anthropogenic Indicators in Pollen Diagrams. Pollen et Spores, 23(2), 255-245.

Bengtsson, L., Enell, M. (1986). Chemical analysis. In: Handbook of Holocene Palaeoecology and Palaeohydrology (pp. 423-448). Berglund, B.E. (Ed.). John Wiley \& Sons Ltd.

Berglund, B.E., Ralska-Jasiewiczowa, M. (1986). Pollen analysis and pollen diagrams. In: Handbook of Holocene Palaeoecology and Palaeohydrology (pp. 455-484). Berglund, B.E. (Ed.). John Wiley \& Sons Ltd.

Brostrom, A. (2002). Estimating source area of pollen and pollen productivity in the cultural landscapes souther Sweden - developing a palynological tool for quantifying past plant cover. Doctoral Thesis, Lund University, Lund, pp. 6-23.

Cohen, A.S. (2003). Paleolimnology: The History and Evolution of Lake Systems. Oxford University Press: New York, pp. 3-19.

O'Connell, M. (1987). Early cereal-type pollen records from Connemara, Western Ireland and their possible significance. Pollen et Spores, 19, 207-224.

Csuros, M., Csuros, C. (2002). Environmental Sampling and Analysis for Metals. Boca Raton: CRC Press.

Davis, M.B. (1973). Redeposition of pollen grains in lake sediments. Limnol. Oceonogr., 18(1), 44-56.

Dean, W.E. Jr. (1974). Determination of carbonate and organic matter in calcareous sediments and sedimentary rocks by loss on ignition: Comparison with other methods. J. Sed. Petrol., 44, 242-248.

Dearing, J.A., Jones, R.T., Shen, J., Yang, X., Boyle, F., Foster, C., Crook, S., Elvin, M.J.D. (2008). Using multiple archives to understand past and present climate-human-environment interactions: The lake Erhai catchment, Yunnan Province China. J. Paleolimnol., 40(1), 3-31.

Eberhards, G., Saltupe, B. (2000). Geological history, relief and deposits of the Lake Engures (Engure) area along the Baltic Sea. Proc. Latv. Acad. Sci., Section B., 54(5/6), 141-147.

Heiri, O., Lotter, A.F., Lemcke, G. (2001). Loss on ignition as a method for estimating organic and carbonate content in sediments: Reproducibility and comparability of results. J. Paleolimnol., 25, 101-110.

Jankovska, V., Komarek, J. (2000). Indicative value of Pediastrum and other Coccal green algae in palaeoecology. Folia Geobot, 35, 59-82.

Juškevičs, V., Mūrnieks, A., Misāns, J. (1999). 42. lapa - Jūrmala. Latvijas geologiskā karte [Sheet 42 - Jūrmala. Geological Map of Latvia], Rīga: Valsts Ģeoloğijas dienests. 52 lpp.

Lepane, V., Morriset, M., Viitak, A., Laane, M., Alliksar, T. (2010). Partitioning of metals between operational fractions in the sediment record from Lake Peipsi. Chem. Ecol., 26, 35-48.

Marchetto, A., Musazzi, S. (2001). Comparison between sedimentary and living diatoms in Lago Maggiore (N. Italy): Implications of using transfer functions. J. Limnol., 60(1), 19-26.

Moore, P.D., Webb, J.A. (1978). An Illustrated Guide to Pollen Analysis. London: Holdder and Stoughtom. 133 pp. (at pp. 16-17).

Rasanen, J., Kentitamies, K., Sandman, O. (2007). Paleolimnological assessment of the impact of logging on small boreal lake. Limnologica, 37, 193-207.

Raukas, A. (2000). Evolution of the Yoldia Sea in the eastern Baltic. Quatern. Internat., 27, 99-102.

Renberg, I., Bindler, R., Brannvall, M.L. (2001). Using the historical atmospheric lead-deposition record as a chronological marker in sediment deposits in Europe. Holocene, 11(5), 511-516.

Rumpe, L. (2003). Paleoenvironmental chages near Gipka and Lake Engure in the western coast of the Gulf of Riga during the Littorina Sea stage. In: Abstract volume (pp. 15-16). Stockholm: Department of Quaternary Geology and Physical Geography, Stockholm University.

Saunders, K.M., Hodgson, D.A., Harrison, J., McMinn, A. (2008). Palaeoecological tools for improving the management of coastal ecosystems: A case study from Lake King (Gippland Lakes) Australia. J. Paleolimnol., 40(1), 33-47.

Schönhofer, F., Wallner, G. (2001). Very rapid determination of ${ }^{226} \mathrm{Ra},{ }^{228} \mathrm{Ra}$ and ${ }^{210} \mathrm{~Pb}$ by selective adsorption and liquid scintillation counting, Radioactiv. Radiochem., 12, 33-38.

Transehe, N. (1937). Par Engures ezeru [On Lake Engure]. Daba un Zinātne, Nr. 2, 33-40.

Vīksne, J. (1997). The Bird Lake Engure. Rīga: Jāṇa sēta. 111pp.

Waters, M.N., Piehler, M.F., Rodriguez, A.B., Smoak, J.M., Bianchi, T.S. (2009). Shallow lake trophic status linked to late Holocene climate and human impacts. J. Paleolimnol., 42, 58-62.

Гринбергс Э.Ф. (1957). Позднеледниковая и послеледниковая история побережья Латвийской CCP [Late Ice-Age and Post-Ice-Age History of the coast of the Latvian SSR]. Рига, 121 с. (in Russian).

Received 9 November 2011

\section{ANTROPOGĒNĀS IETEKMES INTENSITĀTES REKONSTRUKCIJA ENGURES EZERĀ, IZMANTOJOT NOGULUMU SASTĀVA ANALİZI}

Vides piesārņojums ar toksiskiem mikroelementiem ir viena no nozīmīgām vides problēmām. Mikroelementu uzkrāšanās ezeru nogulumos l̦auj novērtēt vispārējos piesārn,ojuma līmeņus ezera sateces baseinā, bet metālu sadalījums nogulumu vertikālajā profilā atspoguḷo cilvēka ietekmes mainības raksturu. Pētījuma mērḳis ir analizēt mikroelementu koncentrāciju Engures ezera nogulumos un izvērtēt to saturu ietekmējošos faktorus. Salīdzinot ar mikroelementu koncentrāciju Rietumeiropas valstu ūdenstilpju nogulumos, metālisko elementu koncentrācijas Engures ezerā ir tuvu fona līmenim. Tomēr pētīto elementu koncentrāciju izmaiṇas nogulumu profilā lauj izvērtēt antropogēnās slodzes mainības raksturu pēdējo 100 gadu laikā un raksturot antropogēno un dabiski noritošo procesu mainības raksturu. 